\title{
ASSAY \\ Innovation in the agricultural sector: Experiences in Latin America
}

\author{
Ricardo X. Chávez, Emma D. Lombeida, Álvaro M. Pazmiño, and Flora del \\ C. Vasconez \\ Universidad Técnica de Babahoyo (UTB), Facultad de Ciencias Agropecuarias. Km 2 1⁄2 vía a Montalvo \\ Babahoyo, Ecuador.
}

\begin{abstract}
R.X. Chávez, E.D. Lombeida, Á.M. Pazmiño, and F. del C. Vasconez. 2015. Innovation in the agricultural sector: Experiences in Latin America. Cien. Inv. Agr. 42(3): 483-492. This article is about the evolution of the agrarian sciences and how innovation plays a crucial role in its development. It also notes how not all innovations have had a positive impact on ecosystems and biodiversity. Such is the case for the relentless advancement of agro-industrial production, which oriented toward obtaining more efficiency and profits, and supported by monocultivation and transgenic varieties through intensive and extensive cultivation. Different alternatives that involve the application of present and ancient knowledge must be used to achieve food sovereignty and safety, based on multidisciplinary knowledge, co-production between public Universities, different types of small-scale farmer and research centers supported by inclusive policies that protect these practices.
\end{abstract}

Key words: Agro-ecology, agronomy, food sovereignty and safety, innovation, technology.

\section{Introduction}

Since the Western world's inception, innovation has been linked to productive and, consequently, social changes. It has been directly associated with science, society and the economy. The first documented steps of its influence on production systems were noted in the Middle Ages through improvements such as the waterwheel and wind mills (Mathias and Davies, 1991). The introduction of these new technologies (This is considered relevant to highlight the relationships between innovation, technology and technique further in this paper) allowed the generation of surpluses in the traditional systems of production and was

Received November 11, 2014. Accepted June 30, 2015. Correspondence author: rickychavez@live.com therefore an effect that allowed the evolution of social systems.

The link between several scientific disciplines and Agronomy began in the nineteenth century. Some of the most important links include Chemistry and industrial and agricultural applications, as well as one of the first scientific contributions of Microbiology through the work of Louis Pasteur (1822-95), who worked with yeasts to make beer and wine, as well as silkworms, livestock and human disease.

The 20th century has been without a doubt one of the most technologically advanced eras in human history, particularly with respect to traditional engineering, medical and biological applications. The early decades of the 20th century gave birth 
to theoretical models allowing the understanding of both known and experimental phenomena. Genetic sciences are a product of this century, as are many new materials, antibiotics, artificial satellites, computers, genetic engineering, and the Internet, among many other inventions that directly or indirectly impact the development of agrarian sciences (Martin, 2000).

It has been shown that all innovative, technical and technological advances may be predisposed to change and could be harmful in their implementation or in their consequences. This article examines the evolution of Agrarian Science as it has always been tied to the development of several innovations. It is important to state that Latin America is vulnerable to practices aimed at high agro-industrialization - which were developed as alternatives to obtain high profit margins - that affect their food sovereignty (food sovereignty is a concept introduced in 1996 by Via Campesina in Rome, on the occasion of the World Summit of the power of the Organization for food and Agriculture (FAO) (Croplife Latin America, 2014a). It is the right of each state to define their own agricultural and food policies according to sustainable development and food security objectives. This implies protection of the domestic market against surplus commodities that are sold cheaper in the international market, as well as the practice of dumping (selling below the cost of production), and the provision of safety measures to guard against harmful practices.

This is the reason why the search for alternatives has been undertaken as a means of achieving total autonomy, and the authors are inclined to find solutions that do not depend on external resources or emulate foreign technologies. Instead, the sustainable management of the Agro-ecology includes using local resources and the active presences of social and economic actors to ensure the food reliance of the people of Latin America.
Innovation and Agronomy, bound to change processes

Understanding the relationship between innovation and Agronomy requires knowledge of the meaning and development of both. The first is linked to the processes of change associated with factors, such as increasing demands - in terms of quality, design or adaptation needs - from consumers, increased competition and the application of technological advances to increase productivity. Whatever the case, the only requirement is the implementation of change (Claver et al., 1998).

Agronomy was born in the 19th century, a product of the growing needs of the market and the producers associated with the progress and dissemination of scientific knowledge. This provoked a radical change in productive models. By implementing technological advances that constantly increase production, taking into account the factors that condition plant production and the techniques for its regulation to obtain maximum or more convenient production, the conservation of the fertility of the soils and the environment is made possible (Sarno and Caruso, 1996). Both processes throughout history have been interconnected. Innovation arises from need, and in this case, the growing population acts as a pressuring force on production systems. These production systems are forced to make changes, either radical or incremental, to accommodate the nutritional needs of the market and to increase their level of growth.

At its inception, agronomic science implied a parting from the established precepts of traditional sciences. The innovations that emerged in this field were radical; they created new products and processes that could not be understood to be the natural evolution of existing products but, rather, products and processes that were considered to be responses to the growing needs of large and populous cities. 
As with all processes affected by advancements and setbacks, this process was not evenly distributed in time, nor was it gradual. Dealing with situations in which the use of new scientific principles causes a break from previous technologies, as was the case for the steam engine, which had a variety of diverse applications across all productive sectors (Benabides, 1998; Kautsky, 1983).

The nature of innovation in Agronomy is primarily technological; it does not recognize that it can exist at the commercial or organizational level. This has emerged after the use of different technologies as a strategic means to introduce changes associated with aspects that are more directly related to means of production (Damanpour, 1987).

Technologies can be created by a producer or, more commonly, by a supplier, whether public private, national or foreign. The only indispensable agent for technological innovation is the production link because it is directly involved in the introduction of change (Allen, 1988; Benabides, 1998). Given its importance, to differentiate the application of the concept of technology, other types of knowledge must be clarified.

Science, technology and technique depend on Agronomy

Science is associated with basic knowledge that is more generic and universally applicable but lacks specific concepts. Innovations were applied during the emergence of agricultural chemistry in the 19th century. Examples include the works of Clement and Derosmes (1806) and Glaser (1860), who perfected the original methods of manufacturing sulfuric acid, the Solvay brothers' (1865) methods of producing soda, Boyer's (1860) production of artificial dyes, and Nobel (1883) and Swan's (1883) production of man-made fibers (Mathias and Davies, 1991; Mason, 1984-1986). Regarding science, technology is, in general, associated with the process of invention, innovation and diffusion, with a practical purpose. The transformation of science in technology requires focusing on scientific knowledge within a specific range of problems.

The most visible impact during the early development of technology was tangible. This impact was associated with the implementation of machinery; a key example was the introduction of tillage to steam through the use of machines for planting and manufacturing (Brooks, 1994) cast iron moldboard plows. Technology is more than just machines. It is also practical knowledge geared toward the action and the systematic application of scientific knowledge or other organized knowledge to practical tasks. Its application is targeted for a specific purpose, to solve problems of action, and its objective is not merely to know, but rather, to act.

Both technique and technology refer to a set of means and knowledge oriented to achieve practical goals. However, even though technique is the ability to use methods, instruments and equipment for practical results, technology also requires a deep understanding of the constraints and perspectives of these skills and the ability to improve the site. Technology implies a capacity to change and improve the knowledge that is not included in the present technique.

Innovation at the technological level is associated with knowledge management. It is achieved by the conversion of tacit knowledge into explicit knowledge that provides answers to specific problems. Innovation is not only relevant to tangible technologies but also to intangible innovations, such as the intellectual property of new patents. In the year 2012, at the intellectual property world office and the patent offices of the United States and Europe, respectively, 439 patents were granted for new agrochemicals. At the same time, Europe and the United States granted 135 patents to 19 different innovators. In the year 2013, nearly half of the granted patents (69) were insecticides, followed by fungicides (36) and herbicides (25) (Crop Life Latin America, 2014). 
Direct impacts of innovation in modern agriculture: Strengths and weaknesses

The increases in the profitability and competitiveness of livestock and agricultural products to modernize farms and investing in technologies in a market saturated with offerings are the means by which some producers have multiplied their performance and improved their quality of production. In the case of agriculture, innovations have occurred not only in the stages of productivity but also in the stages of distribution and marketing (Maté, 2002).

Specific processes, such as the measure of soil performance, which was traditionally based on empirical knowledge and historical returns of the earth to vary or repeat a crop, are today determined by soil analysis, effectively rationalizing land use and saving on cultivation costs, allowing an increase in yields. Custom designed irrigation systems are controlled by software programs that regulate soil moisture and spray fertilizers, depending on the cultivation, and manage to maximize the efficiency of the resources used.

In the case of seeds, plant breeding, which makes it possible to expand production and improve quality, can be adjusted according to the specific demands of the climate and soil. Genetic improvement makes the agrarian sector more competitive in achieving yields similar to those in regions strongly positioned in different cultures with whom it is necessary to compete. In this case, there are many positions on transgenesis due to its indiscriminate use and the creation of new plant species, which can then have a negative impact on human or animal consumption and the ecosystem.

Main agri-food challenges to address in Latin America

The main challenge facing all nations is the preparation for production levels to achieve the capacity to feed the 9 billion people who will inhabit the earth by 2050 ; this represents the greatest challenge that science and innovation have dedicated to this area. Latin America is not exempt from this reality. According to data provided at the VII International Croplife Forum, Latin America presently loses $48 \%$ of its total farming product through different steps in the chain of commercialization (Croplife Latin America, 2014b).

Farmers who have little investment capital to implement substantial innovations or to reverse their dependence adhere to agro-industrial methods, such as monoculture. They also do not exploit their capabilities based on ancestral knowledge, which allows maintenance and coexistence with the dynamics introduced by nature. In addition they use varieties of vegetable species improved through transgenesis that increase performance in the short term but have long-term consequences that they cannot handle. Their ignorance of the contradictory effects of these plant species and the unscrupulous sale of these varieties by transnational corporations cause genetic erosion. For example, the main global producers of soy are located in Latin America (Argentina, Brazil, Paraguay and Uruguay). These countries use methods such as direct seeding, transgenic seeds, herbicides with broad spectrum and selective action on species, such as glyphosate, and high toxicity insecticides, such as endosulfan, to protect soy. The extensive development of this culture has caused several casualties: alternative agricultural products, such as meat, milk, corn, cotton and vegetables; the native forests of Argentina, Paraguay and Brazil; and the natural pastures of traditional livestock in Uruguay (Vásquez, 2006). Farmers who use the agro-industrial model have profoundly modified their local development center and have discarded traditions of ancient culture (use of local varieties, policulture, green fertilizers and biological pest control) and adopted specialized monocultures, high energy consumption and dependence on external inputs that make the conversion to ecological management practically impossible (Altieri and Toledo, 2010). 
The livestock used and the agricultural practices of the extensive and intensive monoculture have huge negative impacts on biodiversity and have high rates of deforestation. In an overall assessment of Latin America, Brazil ranked first in a world ranking of absolute environmental impact values, beating the United States and China. It is alarming that in Brazil, 2.6 million hectares of forests have disappeared in the last decade. For example El Cerrado, which is an important ecoregion in the center of Brazil, lost $48.7 \%$ of its original vegetation coverage due to the expansion of livestock and soy monoculture. The Amazon suffered the greatest impact of deforestation. It is estimated that in 50 years, it lost $17 \%$ of its original coverage (Gudynas and Ghione, 2010).

In the soils of the tropics, the excessive mechanization imposed by the monoculture model accelerates the destruction of the productive soil layer. Unlike the temperate zones, the soils of the tropic have a very low amount of humus due to elevated temperatures and acidity, which do not favor it existence in our ecosystems. Mechanized turning facilitates the loosening of the bio-structure producing soil compaction (Vásquez, 2006).

Government efforts have proven to be insufficient with regard to developing proper knowledge and technologies. Public policies developed by countries such as Chile, Colombia or Peru encourage conventional agricultural production with an intense use of energy and chemicals, which are essentially directed toward exportation, guided by the growing needs of the market and its demands, encouraging their global inclusion as suppliers of agri-food goods. Rather than concentrating on developing alternative, sustainable, and inclusive planning there is intense exploitation and promotion of innovation among local suppliers of inputs (especially small and medium-scale farmers), production and processing companies in rural development (Pomareda and Hartwich, 2006).

Research centers, in this case, Latin American Universities, as centers of higher education and research, have not been involved in the solutions that producers, communities and local and national companies require. Universities have been teaching with a positivist institutional culture, and few have been involved in investigations of this nature. The hypothesis about the causes of the separation between the University and society could be due to mismanagement, lack of clarity regarding priorities, and lack of financing (Pomareda and Hartwich, 2006).

\section{Alternative solutions used by Latin American countries to confront these challenges}

Agronomic sciences must be treated with a transdisciplinary and complex approach, increasing the use of information and communications technologies in rural management, and developing multidimensional strategies. These elements also have an impact throughout society, and the development of innovation should not rely only on new technologies but also on the return to ancestral knowledge alternatives that allow for the evolution of farming, creating incentives and institutional protection for farmers to continue traditions. Encouraging the younger generations, who may decide to replace their predecessors in their family business, is critical. Restoring the means of production with small gardens that have short agricultural production cycles is another option.

Universities play a key role in continuous training, and they must be present throughout the production chain. They establish a means for the collaboration of knowledge, empowering the producers of different technologies and agricultural practices that increase productivity and ensure the quality of your product.

Opportunities to develop the knowledge and technology capable of improving agricultural products, to add value to and to generate income for local primary producers, processors and other stakeholders exist. The specifications of marketing and innovation that are required within the supply 
chain, including primary production, processing, and marketing of agri-business and consumers themselves, should be identified for this purpose.

The area mentioned above has not been properly tapped by earlier models of agricultural development in Latin American countries. They have underutilized their capacity to contribute on this end. This has created a vacuum where the private providers of knowledge and technology that offer different services to producers and industries that need innovation and have the capital to invest in it prevail and where the University and public sectors have failed. The main products that are provided are seed packages, plant tissue, embryos, agro-chemical equipment, bio-fertilizers and delivery services, which allow for quality-controlled, certified export and storage under controlled conditions. The countries that stand for private innovation generators include Brazil, Chile, and Mexico, whereas other countries are more prominent vendors of private knowledge.

Some of the associations of producers that have established their own divisions and facilities for research and technology transfer, such as the National Coffee Research Center and the National Federation of Coffee Growers of Colombia, should be enhanced. There have been very few successful experiences in this field as the generalized responses of these producers are slow and insufficient. Depending on their subsidies, they should raise their capacity in response to the technological demands of their members.

One of the many questionable alternatives involves being dependent on transnational companies for agricultural and agro-industrial inputs for production and processing - whether of seeds, fertilizers, pesticides or machinery. These companies, which are protected by the veil of the green revolution, develop elaborate marketing campaigns to sell their products and raise awareness about their benefits, spreading knowledge about the use of technologies that promote broader technological packages. In the seeds sector, most of the private initiatives are oriented toward commercial hybrids of crops, such as soybeans or corn, and not toward easily reproduced seeds, such as open-pollinated grains or potato.

The ability of local knowledge as an alternative to expensive products that can be purchased by large industries and that small producers and processors do not have access to should also be developed. There are also cases where they copy from others, improve their businesses by on trial and error, or, on very rare occasions, develop autonomous solutions without external support. These endogenous efforts to develop knowledge and technology are limited because the creation of, experimentation on and implementation of new technologies are difficult due to time and resources that small producers are not willing to risk if the technology is not satisfactory.

To become competitive players in domestic and international markets, farmers have largely used an innovative agrochemical that allowed the production of abundant and safe food, providing greater efficiency and better profitability, and decreasing the chances of crop losses. However, long term impacts of the use of this agrochemical must be taken into account. Currently, the world production of fruit and vegetables, fodder and fiber depends on 30 to $40 \%$ of agro-chemicals to reduce the effects of pests and diseases. Another action being implemented is the decrease in the dosage of kg to grams per hectare. Dose reduction offers more security to the workers handling crops. The environmental imprint of the chemicals used in agriculture decreases and improves the discrimination of non-goal organisms, which suffer increased degradation by microorganisms (CropLife Latin America, 2014b).

Agro-ecology offers more options for mitigating the emissions of some greenhouse gases, such as reducing emissions and increasing collection, as well as more tools to preserve biodiversity and reduce environmental pressure. 
Agro-ecological practices include retiring the use of agro-chemicals, and reducing the pollution of soil and water. The use of local varieties of biological pest control generates higher margins to conserve biodiversity. Their polyculture and rotations encourage agro-biodiversity and ecological complementarity, as opposed to conventional monocultures.

The bond between conventional agriculture and livestock and their effects on biodiversity and climate change can begin to be reversed by betting once again on rural development, which is a theme that runs transversally through productive, economic, social and environmental dimensions. In this way, agro-ecology offers many alternatives for change (Gudynas and Ghione, 2010).

\section{Pathways for achieving food sovereignty and safety in Latin America}

The agribusiness model of industrialized countries in Latin America has been applied as one of the economic and agrarian alternatives of development, with little success, because it does not adapt to conditions where priority is given to economic efficiency, and it does not take into account widespread conditions of vulnerability associated with considerable segments of the population that are isolated from new technological systems (Sutz, 1997).

It is important to highlight that this model has been developed and has succeeded in the European context because of its advances in a sustained protectionist space in huge grants and subsidies based on a strong economic presence of the state in the sector, in which companies and agribusiness farms operate (Rosset, 2004).

Specialized agricultural sectors are aligned to export and raise the efficiency benefit economically to national economies in the short term. In terms of medium and long term use, dedicating large areas to the cultivation of genetically modified crops for biofuels by shipping more each day for human consumption while the risk associated with consuming such crops is still unknown (Pengue, 2005) may cause numerous environmental, economic and social problems.

The process of innovation in the Latin American countries should concentrate on a process of complementarity among scientific, local and ancestral knowledge. The fundamental development of these is the joint work of Universities, research centers and society, small-scale farmers, trade unions and local managers, in general, remaining in constant dialogue and feedback based on public policies in support of the realization of this co-production of knowledge.

Innovation and the search for alternatives in the Agronomy sciences must be established under guidelines in which Latin American countries achieve food sovereignty and security. The conventional approaches of the alternatives previously assaulted this vision. Usually, the traditionalist approach to innovation reaches from the perspective of the technology package of the green revolution and the biotechnology revolution in the agricultural field. These have been widely criticized in all Latin American contexts for their impact on the environment and reduced positive socio-economic impact on Latin America's inhabitants.

It was mentioned previously in this paper that the intensive culture applied by the agro-industrial models based on monocultures, genetic modified crops, agrofuels and the high price of fertilizer increase pressure on already damaged ecosystems, decreasing the ability of theses ecosystems to produce food. For this reason, the imbalance between agro-industrial models and the local alternatives of sustainable agro-ecological management is a direct cause of the threat to the food security of the people.

Agro-ecological farmer models are based on the use of various species of cattle and thousands of 
edible plants that allow a genetic variety, as opposed to a lack of variety, in industrial models. Small-scale polyculture consisting of systems with local varieties allows the adaptation to different climates and soils, feeding the latter with organic plant and animal matter instead of chemical fertilizers. This alternative coexists with nature and supports the biological control of pests and natural pollination, among the other benefits obtained without affecting ecosystems.

Ecosystems have demonstrated high levels of biological diversity that are key to regulating the functions of these ecosystem. Creative applications to systems and technologies for the management and conservation of the landscape, soil and water resources that allow the establishment of diversified agricultural systems that are resilient to human or environmental changes. These are based on both the management of traditional knowledge and the innovations of agriculture that are governed by socio-cultural institutions and supported by collective forms of social organization (Dewalt, 1994; Koohafkan and Altieri, 2010).

As props in the development of agro-ecological techniques place emphasis on Brazil with the union of efforts among Non-Governmental Organizations (NGOs), Universities, research and extension centers, initiatives from the state and federal government of agro-ecological development and rural organizations culminated in the 2006 development of the national articulation of Agro-ecology. Cuba promotes organic agriculture, urban gardens, agricultural systems of low scale, animal traction and biological control of pests, which became pillars (Machin-Sosa et al., 2010). Nicaragua, Guatemala and Honduras can be seen in a different way, where promoters or farmers successfully applied alternatives and proposed them to the small-scale farmer, and from their experiences, they trained and inspired other farmers. These developers are involved in a process of dissemination agro-ecological knowledge without the presence of researchers or extension workers. In the Andean region, the presence of a peasantry with deep cultural roots, ancestral agricultural knowledge and a strong resistance and political activity, especially in rural areas in Peru, Ecuador and Bolivia, this represented a very timely scenario for the development of sustainable agro-ecology. They demonstrate that the indigenous movement is the main force facing neoliberal policies, at the same time manifesting its support for progressive Governments, such as the administrations of Presidents Rafael Correa and Evo Morales. A deep understanding of the use of the Andean environment, which was learned over centuries, allowed the development of different strategies to minimize risks of droughts, frosts and hailstorms, as well as to face the biophysical constraints of the Andes. In Mexico, agro-ecological experiences involve additional socio-ecological management systems of natural resources, including forests, restoration of degraded lands and conservation of agro-biodiversity. Over the past three decades, many communities have begun to regain control over their forest properties and are engaged in a wide range of ecological timber and non-timber production (Altieri and Toledo, 2010).

Sustainable agro-ecology management provides the principles for designing elastic and resistant agroecosystems to political, social, environmental and commercial variations. This will simultaneously ensure strongly interrelated food, energy and technological sovereignty.

The most important conclusions of the study are described below.

Agronomy as science has evolved since its inception, and innovation has played a protagonist role in its development through time. Currently, agronomic science must use other tools to solve complex problems involving not only this field but also politics, society and the environment, which require various types of skills and multidisciplinary specialists.

Relations between Universities, innovation centers, governments, public policies and producers 
must be consistent and in line with a governing development policy and technologies that allow the progress of the production of small and mediumsized producers that ensure food sovereignty, as well as the progress of large industries to export on a basis that is sustainable and inclusive, valuing agro-ecological alternatives and innovation requiring few resources for its implementation, as well as support for family agriculture.

The articulation of the political bodies and the operational bodies - governments and Universities - contributes to the multidisciplinary and ongoing training. This allows the co-production of knowledge and the articulation of participatory research and training, creating spaces of experimentation and learning that foster the development of specific innovations that increase the innovative capacity of the whole system, establishing a dialogue between local ancient knowledge and modern scientific knowledge.
The gap caused by the insufficient provision of knowledge by public organizations allows this space to be occupied by private organizations, which, in addition to copying and importing overseas technologies, do no develop endogenous potentialities and marginalize family agriculture and the peasantry, who cannot access these technologies.

Endogenous innovation and Agro-ecology associated initiatives do not have enough financial support and should be prepared to provide solutions that can compete in the international environment.

A robust and sustainable supply chain and a more efficient and optimal use of resources is achieved by supporting local agriculture, greater and better yields with less inputs and innovation for better and more efficient agriculture cooperatives and agricultural unions, producers, agricultural companies, academics, researchers and sector associations.

\section{Resumen}

R.X. Chávez, E.D. Lombeida, Á.M. Pazmiño y F. del C. Vasconez. 2015. La innovación en el sector agrario: Experiencias en Latinoamérica. Cien. Inv. Agr. 42(3): 483-492. Este artículo trata de la evolución de las ciencias agrarias en el tiempo y como la innovación juega un papel fundamental en su desarrollo. También apunta que no todas las innovaciones y avances tecnológicos realizados han tenido un impacto positivo en los ecosistemas y la biodiversidad como es el caso del avance implacable de la producción agroindustrial orientada a obtener mayores márgenes de eficiencia y ganancia apoyados fundamentalmente en el monocultivo y el empleo de variedades transgénicas mediante cultivos intensivos y extensivos. Para el logro de la soberanía y seguridad alimentarias deben fomentarse alternativas que involucren la aplicación de los conocimientos científicos actuales y los saberes locales y ancestrales, que atesoran nuestras regiones y campesinado tan variado y heterogéneo que con la coproducción de conocimientos multidiciplinarios con universidades públicas, y centros de investigaciones respaldados por políticas inclusivas y que protejan estas prácticas se puede lograr mitigar estas amenazas.

Palabras clave: Agronomía, agroecología, innovación, soberanía y seguridad alimentarias, tecnología. 


\section{References}

Allen, T.J. 1988. Managing the Flow of Technology. Cambridge, Massachusetts: The MIT Press.

Altieri, M. A., and Toledo, V. M. 2010. La revolución agroecológica de América Latina: Rescatar la naturaleza, asegurar la soberanía alimentaria y empoderar al campesino. El Otro Derecho 42:164-202.

Benabides, C. 1998. Tecnología, Innovación y Empresa. Madrid: Pirámide.

Brooks, H. 1994. The Relationship between science and technology. Research Policy 23: 477-486.

Claver, E., Llopis, J., García, D., and Molina, H. 1998. Organizational culture for innovation and new technological behavior. The Journal of High Technology Management Research 9: 55-68.

CropLife Latin America. 2014a. ¿Por qué necesitamos innovar en agricultura? Available online at: http://www.croplifela.org/es/documentos-croplife/productividad-de-cultivos/173-porque-necesitamos-innovar-en-agricultura.html (Website accessed: October 5, 2014).

Croplife Latin America. 2014b. VII Foro Internacional Croplife Latin America. Available online at: http://www.croplifela.org/es/vii-foro-ecuador. html?start=1 (Website accessed: October 24, 2014).

Damanpour, F. 1987. The adoption of technological, administrative, and ancillary innovations: Impact of organizational factors. Journal of Management 13:675-688.

Dewalt, B. 1994. Using indigenous knowledge to improve agriculture and natural resource management. Human Organization 53:123-131.

Gudynas, E., and S. Ghione. 2010. Agricultura y ganadería, biodiversidad, cambio climático: estrechamente vinculados. LEISA Revista de Agroecología 26:40-43.

Kautsky, K. 1983. La cuestión agraria. Bogotá, Colombia. Editorial Latina.

Koohafkan, P., and Altieri, M. A. 2010. Globally important agricultural heritage systems: a legacy for the future. Rome, Italy. UN-FAO.
Machin-Sosa, P., A.M. Roque -Jaime, D.R. Avila -Lozano, and P. Rosett. 2010. Revolución Agroecológica: el Movimiento de Campesino a Campesino de la ANAP en Cuba. Habana, Cuba. ANAP.

Martín, M.A. 2000. Desafíos de Europa en el siglo XXI. Academia Europea de Ciencias y Artes. Bilbao: Mimeo.

Mason, S.T. 1984-1986. Historia de las Ciencias. Madrid, España: Alianza Editorial (5 vols.).

Maté, V. 2002. La incorporación de la tecnología al sector agrario y pesquero. In: Colección Innovación Práctica. Informar sobre Innovación (p. 95-101). Madrid, España: Fundación Cotec para la Innovación Tecnológica.

Mathias, P., and Davies, J. A. (eds.). 1991. Innovation and Technology in Europe. From the Eighteenth Century to the Present Day. Oxford: Blackwell.

Pengue, W. 2005. Agricultura industrial y transnacionalización en América Latina. PNUMA, Buenos Aires.

Pomareda, C., and F. Hartwich. 2006. Innovación agrícola en América Latina. Comprendiendo el papel del Sector Privado. International Food Policy Research Institute, Lima.

Rosset, P. 2004. Soberanía Alimentaria: Reclamo Mundial del Movimiento Campesino. Available online at http://www.odg.cat/documents/formacio/Sessio_1_juny_Document1_FerranGarcia. pdf (Website accessed: October 2, 2014).

Sarno, R., and P. Caruso. 1996. L'agronomia del territorio: il ruolo delle scienze agronomiche nella formazione professionale. Rivista di Agronomía 30: 297-309.

Sutz, J. (ed.). 1997. Innovación y desarrollo en América Latina. Consejo Latinoamericano de Ciencias Sociales-CLACSO, Agencia Española de Cooperación Internacional. Edit. Nueva Sociedad.

Vásquez, D. 2006. La agronomía y el campo. Revista Universidad de Caldas 26:207 - 220. 